УДК: 331.2:323.32 (477)

JEL Classification: D 14

T. C. IГHATEHKO,

acnipaнm,

ДВНЗ "Університет банківської справи" Начіонального банку України

\title{
Чинники формування \\ та регулювання доходів населення Украйни в контексті становлення середнього класу
}

Досліджено структуру та динаміку доходів населення України; проаналізовано стан державного регулювання доходів та заробітної плати; проведено очінювання рівня зайнятості як передумови збільшення доходів населення. Зроблено висновок щодо необхідності удосконалення механізмів держсавного регулювання доходів, подальщої розбудови фондового ринку та більщ досконалого обгрунтування розмірів мінімальної заробітної плати.

Ключові слова: середній клас, доходи населення, заробітна плата, мінімальна заробітна плата, доходи від власності, диферениійоване оподаткування.

Постановка проблеми. Основним критерієм ідентифікації середнього класу є рівень доходів, який забезпечує споживання за прийнятими в суспільстві стандартами. Збільшення частки середнього класу в структурі суспільства можливе лише за умови підвишення доходів населення.

Процес формування середнього класу в Україні перебуває на початковому рівні, що пояснюється, насамперед, низьким рівнем життя населення. Крім того, велика кількість людей, які наближаються до статусу середнього класу, отримують значну частину доходів без реєстрації і сплати податків. Це зумовлює певну суперечливість їх відносин із державою, а відтак і труднощі на шляху реалізації їх суспільної функції бути основою соціально-політичної стабільності.

Завданням політики формування середнього класу є розроблення механізмів підвищення життєвого рівня населення, що є нелегкою задачею, яку необхідно вирішити в умовах суспільної трансформації на засадах оптимальної узгодженості інтересів різних соціальних верств населення. Складність цієї проблеми вимагає чіткого системного підходу до ії вивчення та вирішення.

Аналіз останніх досліджень та публікацій. Дослідженню питань формування та регулювання доходів населення присвячені праці таких вітчизняних вчених як С. Слава, О. Висіч, В. Павлович [2], Н. Карпенко [6], О. Мельниченко, Р. Гулій [7], О. Драган [9]. Водночас відсутність в Україні реальних реформ щодо регулювання заробітної плати та важливість вирішення проблеми формування середнього класу обумовлюють необхідність подальших досліджень у цій сфері.

Метою статті є дослідження рівня доходів населення України в контексті становлення середнього класу та аналіз механізмів державного регулювання доходів і заробітної плати.

Виклад основного матеріалу. Середній клас найчастіше ідентифікується за рівнем доходу, який дозволяє людині не тільки задовольняти базові потреби, а й розвиватися, збільшувати заощадження, мати можливість інвестувати, гідно проводити дозвілля. В Україні більшість населення не має достатніх доходів, які б відповідали стандартам середнього класу. Структуру доходів населення та їі зміни за період 2012-2016 років проаналізовано в табл. 1 .

Т. С. Ігнатенко, 2017 
Таблиия 1

Структура доходів населення Украйни за 2012-2016 pp., \%

\begin{tabular}{|c|c|c|c|c|c|c|}
\hline Статті доходів & 2012 p. & 2013 p. & 2014 p. & $2015 \mathrm{p}$. & $2016 \mathrm{p}$. & \begin{tabular}{|c|} 
Зміни \\
$(2016-2012)$, \\
,+- \\
\end{tabular} \\
\hline Всього доходів & 100,0 & 100,0 & 100,0 & 100,0 & 100,0 & $\mathrm{x}$ \\
\hline \multicolumn{7}{|l|}{ у тому числі: } \\
\hline заробітна плата & 39,2 & 39,9 & 40,1 & 37,9 & 40,8 & $+1,6$ \\
\hline $\begin{array}{l}\text { прибуток та змішаний } \\
\text { доход }\end{array}$ & 19,7 & 19,7 & 21,1 & 25,0 & 23,0 & $+3,3$ \\
\hline доходи від власності & 5,2 & 5,1 & 5,9 & 3,9 & 3,8 & $-1,4$ \\
\hline $\begin{array}{l}\text { соціальні допомоги та інші } \\
\text { поточні трансферти }\end{array}$ & 35,9 & 35,3 & 32,9 & 33,2 & 32,4 & $-3,5$ \\
\hline \multicolumn{7}{|l|}{3 них: } \\
\hline соціальні допомоги & 21,3 & 21,3 & 18,3 & 17,8 & 16,4 & $-4,9$ \\
\hline інші поточні трансферти & 3,2 & 2,8 & 4,3 & 4,9 & 5,0 & $+1,8$ \\
\hline $\begin{array}{l}\text { соціальні трансферти в } \\
\text { натурі }\end{array}$ & 11,4 & 11,2 & 10,3 & 10,5 & 11,0 & $-0,4$ \\
\hline
\end{tabular}

Джерело: розраховано за [1]

Розрахунки показують, що головним джерелом доходів населення країни $\epsilon$ заробітна плата, частка якої в структурі доходів у 2016 р. становила $40,8 \%$, а у 2012 $39,2 \%$. На другому місці за питомою вагою в структурі доходів знаходяться соціальні допомоги та інші одержані поточні трансферти (35,9\% у 2012 р. та 32,4\% у 2016 р.). Певну роль у загальних доходах домогосподарств України відіграють доходи від підприємницької діяльності (19,7\% у 2012 р. та 23,0\% у 2016 р.). Незначну частку в структурі доходів мають доходи від власності (5,2\% у 2012 р. та 3,8\% у 2016 р.).

Аналізуючи зміну структури доходів населення, можна зробити висновок про зростання частки таких складових як заробітна плата (на 1;6 відсот. пунктів), прибуток та змішаний доход (на 3,3 в. п.), а також інші поточні трансферти (субсидії на оплату житлово-комунальних послуг) (на 1,8в. п.). За рахунок зростання питомої ваги цих трьох складових доходів відбулося зменшення частки доходів від власності (на 1,4 в. п.), соціальних допомог (на 4,9 в. п.) та соціальних трансфертів у натурі (на 0,4 в. п.).

Зростання частки заробітної плати у структурі доходів населення є позитивною тенденцією, враховуючи те, що в економічно розвинутих країнах цей показник складає більше $50 \%$. Низька частка оплати праці у сукупних доходах та висока частка соціальних допомог свідчить про неефективний механізм формування доходів та поширення бідності.

Науковцями з метою оцінювання ефективності державної політики регулювання оплати праці аналізуеться також частка заробітної плати в структурі ВВП. В Україні вона становить $41,3 \%$ [1], тоді як у розвинутих країнах, таких як США і Японія, - більше $75 \%[2$, c. 22$]$.

Прибуток та змішаний доход - це доход, який одержує фізична особа в результаті виробничої діяльності, за винятком витрат, пов'язаних з їі здійсненням. Частка цієї складової зростає внаслідок збільшення кількості фізичних осіб-підприємців (ФОП). У 2012 р. їх налічувалось 1,24 млн, а у 2016 - 1,56 млн, що на 25,8\% більше [1].

Аналіз динаміки номінальної заробітної плати (рис. l) свідчить про щорічне зростання ії рівня, однак розмір заробітної плати у доларовому еквіваленті різко знижується.

У 2016 р. номінальна середньомісячна заробітна плата склала 5183 грн, що перевищує ії розмір у 2012 р. на 71,3\%. У порівнянні з 2015 р. вона збільшилась на 23,6\%. У доларовому еквіваленті заробітна плата у 2016 р. дорівнювала 190,6 дол., що вдвічі менше її рівня у 2012 p. 

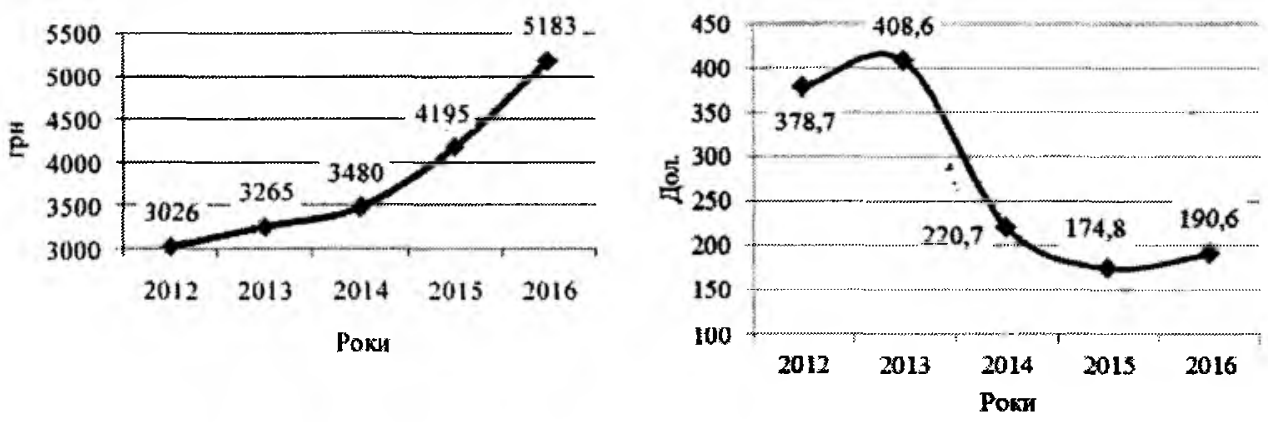

Рис. 1. Номінальна заробітна плата у гривневому та доларовому еквіваленті за період 2012-2016' pp.

Джерело: побудовано за $[1 ; 3]$

Дпя сучасного українського суспільства характерним є різке майнове розшарування, глибока диференціація доходів населення та загрозливі масштаби бідності. Згідно 3 офіційними статистичними даними, грошові доходи $10 \%$ найбільш забезпеченого населення перевищували у 2016 р. доходи $10 \%$ найменш забезпечених у 3,9 раза [4] Проте, на думку вчених, доходи 10\% найбагатших і 10\% найбідніших українців 3 урахуванням тіньових доходів відрізняються у 40 разів [5].

Економісти стверджують, що зазначена невідповідність обумовлена двома причинами. По-перше, це неврахування в розрахунках значної частки тіньової економіки; по-друге, в Україні між невеликою чисельністю заможних лю́дей і значною чисельністю бідних практично відсутній середній клас, який би урівноважував цю ситуацію.

3 точки зору науковців, одним із механізмів державного регулювання доходів $\mathrm{i}$ заробітної плати є їх перерозподіл через бюджет шляхом диференційованого оподаткування різних груп одержувачів доходів та соціальних виплат. При цьому значна частка національного доходу переходить від прошарків населення із високими доходами до прошарків із відносно низькими доходами, що приводить до збільшення загальних витрат споживачів i, відповідно, обсягів споживання товарів і послуг [6]. Отже, суттєва роль у регулюванні доходів підприємців і найманих працівників належить державній системі оподаткування. Проте в Україні соціальний потенціал податкової системи практично не використовується, перерозподілу доходів від високозабезпечених до малозабезпечених верств населення майже не відбувається.

Важливу роль у регулюванні доходів населення відіграє мінімальна заробітна плата (МЗП), яка виконує низку функцій [7]: відтворювальну (забезпечення відтворення робочої сили); еталонну (формування базового орієнтира у встановленні рівня державної соціальної підтримки і пенсійного забезпечення населення); регулювальну (створення умов для диференціації трудових доходів і ведення переговорів між найманими працівниками та роботодавцями); соціальну (гарантування задоволення основних життевих потреб працівників).

В Україні відбулася реформа мінімальної заробітної плати. На сьогодні МЗП являє собою законодавчо встановлений розмір заробітної плати за просту, некваліфіковану працю, без урахування доплат, надбавок, заохочувальних і компенсаційних виплат, нижче якого не може провадитися оплата за виконану працівником місячну, а також погодинну норму праці (обсяг робіт).

Мінімальна заробітна плата $є$ нижньою межею вартості праці, а їі розмір не може бути нижчим за базовий державний соціальний стандарт - грошову величину прожиткового мінімуму для працездатної особи. 31 січня 2017 р. розмір мінімальної заробітної плати було підвищено 31600 до 3200 грн.

Співвідношення між мінімальною та середньомісячною заробітною платою вимірюється індексом Кейтца. Згідно з Європейською соціальною хартією цей індекс не має бути меншим за $60 \%$, а за висновками Міжнародної комісії СС - має бути на рівні 68\% [7]. 3 підвищенням мінімальної заробітної плати значення індекса Кейтца в Україні збільшується (табл. 2). 
Індекс Кейтца в Украйні у 2015-2017 pp.

\begin{tabular}{|l|c|c|c|}
\hline \multicolumn{1}{|c|}{ Показники } & 2015 p. & 2016 p. & I кв. 2017 р. \\
\hline $\begin{array}{l}\text { Мінімальна заробітна плата (в серед- } \\
\text { ньому за рік, у 2015 та 2016 рр.), грн }\end{array}$ & 1271 & 1439 & 3200 \\
\hline Середньомісячна заробітна плата, грн & 4195 & 5183 & $\mathbf{6 4 0 7}$ \\
\hline Індекс Кейтса, \% & 30,3 & 27,8 & 49,8 \\
\hline
\end{tabular}

Джерело: розраховано за [1]

Проведені розрахунки свідчать, що у 2015 р. індекс Кейтса складав $30,3 \%$, а в $2016-27,8 \%$. 3 підвищенням мінімальної заробітної плати до рівня 3200 грн значення індекса у першому кварталі 2017 р. зросло до $49,8 \%$, однак все ж таки не досягло нормативу.

Аналіз структури доходів населення, проведений у табл. 1, свідчить про низьку частку доходів від власності в структурі доходів населення. Доходи від власності - це первинні доходи, які одержують власники фінансових та нефінансових активів (землі, майнових прав і т. д.) від надання їх у користування іншим інституційним одиницям. Вони включають: дивіденди, відсотки від акцій, внесків та дыоговорів оренди земельних ділянок та майна; доходи населення від власності на землю; відсотки за вкладами, отримані від банків фізичними особами.

В розвинутих країнах населення i, зокрема, представники середнього класу $є$ одними із найбільших постачальників інвестиційного капіталу на фондовому ринку. Маючи високий рівень заощаджень, вони купують облігації державних позик та корпоративні цінні папери, керуючись мотивом збереження та примноження наявних коштів, отримуючи значні доходи від власності.

Науковці визначають інструменти ринку цінних паперів як потенційно перспективні об'єкти інвестицій для домашніх господарств, проте в Україні спостерігається надзвичайно низький рівень участі населення в купівлі-продажу цінних паперів. Причинами такої ситуації є невисокі доходи українців i, відповідно, низька схильність до заощаджень. За результатами опитувань громадян України в рамках проекту Центру Разумкова зроблено висновок, що чверть представників середнього класу взагалі не мають заощаджень і лише $15 \%$ вважають, що в разі втрати джерела доходу наявних заощаджень їм вистачить не менше ніж на півроку [8, с. 77].

3 точки зору фахівців, основними причинами низької інвестиційної активності населення України також $є$ втрата довіри до українських цінних паперів, слабкість фінансових інструментів, нерозвиненість фондового ринку, фінансова неграмотність населення [9, с. 134]. Домогосподарства не зацікавлені вкладати у фондовий ринок, страхові компанії чи недержавні пенсійні фонди (НПФ), оскільки такі інвестиції довгострокові та не завжди гарантують збереження вартості вкладень.

Наявність прийнятного рівня доходів напряму пов'язана з рівнем зайнятості населення. В табл. 3 проаналізовано динаміку рівня зайнятості за віковими групами населення у 2014-2016 роках.

Таблищя 3

Рівень зайнятості населення Украйни у 2014-2016 рр., \%

\begin{tabular}{|l|c|c|c|c|}
\hline \multicolumn{1}{|c|}{ Групи населення } & 2014 p. & 2015 p. & 2016 p. & $\begin{array}{c}\text { 3міни } \\
\text { (2016-2014), } \\
+,-\end{array}$ \\
\hline Все населення & 56,6 & 56,7 & 56,3 & $-0,3$ \\
\hline в т. ч. за віковими групами, років & & & & \\
\hline $15-24$ & 29,5 & 28,2 & 27,0 & $-2,5$ \\
\hline $25-29$ & 71,6 & 71,8 & 69,8 & $-1,8$ \\
\hline $30-39$ & 76,4 & 76,7 & 74,7 & $-1,7$ \\
\hline $40-49$ & 78,4 & 78,6 & 78,2 & $-0,2$ \\
\hline $50-59$ & 59,4 & 61,7 & 62,4 & $+3,0$ \\
\hline $60-70$ & 15,5 & 14,5 & 14,3 & $-1,2$ \\
\hline
\end{tabular}

Джерело: розраховано за [1]

\begin{tabular}{ll}
\hline$y$ & SCIENTIFIC BULLETIN OF THE NATIONAL ACADEMY \\
OF STATISTICS, ACCOUNTING AND AUDIT, 2017, № 4
\end{tabular}


В Україні відбувається зниження рівня зайнятості у всіх вікових групах населення, крім групи 50-59 років. Аналіз показує, що найбільше зниження рівня зайнятості відбулося у двох вікових групах - 15-24 років і 25-29 років.

До першої групи входять випускники вищих навчальних закладів (ВНЗ), які $\epsilon$ потенційними представниками середнього класу і працевлаштування яких на ринку праці пов'язано 3 низкою проблем. Труднощі з працевлаштуванням випускників ВН3 породжені низкою причин, серед яких слід виділити такі:

$>$ недостатня кваліфікація випускників, невідповідність ії вимогам роботодавців;

$>$ наявність диспропорцій між попитом та пропозицією дипломованих спеціалістів унаслідок відсутності державного прогнозування у спеціалістах з вищою освітою; такі диспропорції обумовлюють появу феномена "надлишкової освіти" $[10$, с. 6];

$>$ невисока заробітна плата фахівців з вищою освітою в Україні. Так, середня заробітна плата в сфері освіти дорівнювала у 2016 р. 3769 грн, що на 27,3\% нижче середнього рівня в країні [1]. Для порівняння: середня місячна заробітна плата вчителя в Німеччині складає 1380 євро, в Естонії 1135 євро [11].

Отже, для включення молоді i, зокрема, випускників ВНЗ до представників середнього класу необхідно розробити систему заходів для підвищення зайнятості цих категорій населення.

Державною службою статистики України проводяться вибіркові опитування членів домогосподарств, які беруть участь. в обстеженні умов життя, щодо самооцінки домогосподарствами рівня своїх доходів. Результати опитування, проведеного у січні 2017 року, наведено на рис. 2.

Підсумки опитування свідчать, що частка домогосподарств, які надали високу оцінку своїм річним доходам (було цостатньо і роб́или заощадження), скпадає 6,2\%. Частка сімей, які оцінили рівень своїх доходів як достатній, склала $45,7 \%$.

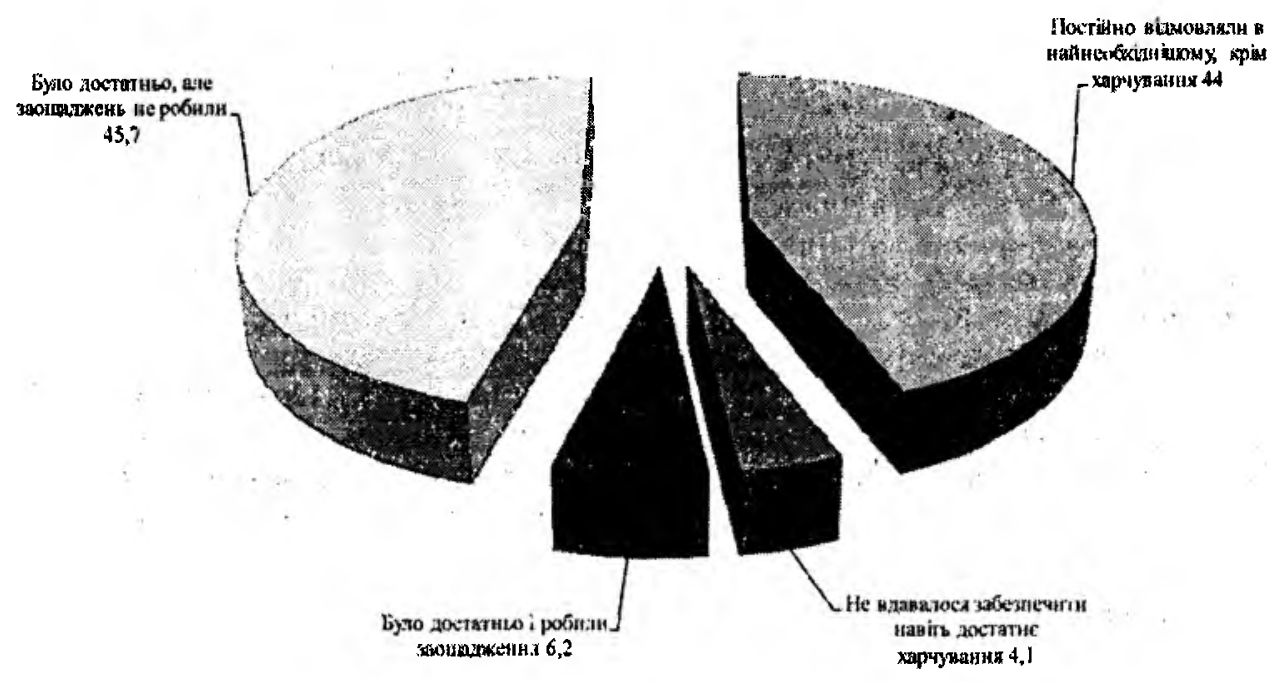

Рис. 2. Розподіл домогосподарств України за самооцінкою рівня іх доходів, \%

Джерело: побудовано за даними [12]

$44 \%$ обстежених домогосподарств вважали свій доход достатнім дия нормального харчування, а 4,1\% домогосподарств не змогли забезпечити навіть ростатнє харчування. Самооцінка рівня своїх доходів відрізнясться в залежності від місця проживання опитуваних (табл. 4). 
Розподіл домогосподарств. України за самооцінкою рівня їх доходів залежно від місця проживання

\begin{tabular}{|c|c|c|c|c|c|c|}
\hline & \multirow{2}{*}{\multicolumn{2}{|c|}{$\begin{array}{c}\text { Всі } \\
\text { домогосподарства }\end{array}$}} & \multicolumn{4}{|c|}{ у тому числі проживають } \\
\hline & & & \multicolumn{2}{|c|}{$\begin{array}{c}\text { y міських } \\
\text { поселеннях }\end{array}$} & \multicolumn{2}{|c|}{$\begin{array}{l}\text { у сільській } \\
\text { місцевості }\end{array}$} \\
\hline & 2015 & 2016 & 2015 & 2016 & 2015 & 2016 \\
\hline $\begin{array}{l}\text { Кількість } \\
\text { домогосподарств, тис. }\end{array}$ & $1,5073,7$ & 15033,4 & 10125,0 & 10109,4 & 4948,7 & 4924,0 \\
\hline $\begin{array}{l}\text { Розподіл } \\
\text { домогосподарств, \%: }\end{array}$ & & & & 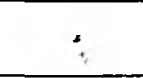 & & \\
\hline $\begin{array}{l}\text { - було достатньо і робили } \\
\text { заощадження }\end{array}$ & 6,2 & 6,2 & 5,7 & 6,0 & 7,3 & 6,6 \\
\hline $\begin{array}{l}\text { - було достатньо, але } \\
\text { заощаджень не робили } \\
\end{array}$ & 45,7 & 45,7 & 46,8 & 46,0 & 43,3 & 45,1 \\
\hline $\begin{array}{l}\text { - постійно відмовляли } \\
\text { собі у найнеобхіднішому, } \\
\text { крім харчування }\end{array}$ & 43,2 & 44,0 & 42,8 & 44,3 & 43,9 & 43,3 \\
\hline $\begin{array}{l}\text { - не вдавалося } \\
\text { забезпечити навіть } \\
\text { достатнє харчування }\end{array}$ & 4,9 & 4,1 & 4,7 & 3,7 & 5,5 & 5,0 \\
\hline
\end{tabular}

Джерело: побудовано за даними [12]

Слід зазначити, що сільські домогосподарства дали більш високі оцінки рівня добробуту, ніж місцькі. Рівень своїх доходів як достатній для того, щоб робити заощадження, оцінили у 2016 р. 6,6\% сільських домогосподарств, що на 0,6 в. п. більше, ніж серед міських. Така ситуація в значній мірі обумовлена дещо нижчими стандартами життя в сільській місцевості та суттєвим впливом особистих підсобних господарств на самозабезпечення сільських домогосподарств. Разом і тим, 5,0\% сільських домогосподарств (у 2015 р. - 5,5\%) вказали, що рівень їх доходів не забезпечував навіть достатнє харчування, що в 1,4 раза вище аналогічного показника серед міських домогосподарств.

Одним із методологічних підходів у статистиці до визначення суб'єктивної межі бідності є отримання відповідей на запитання, яка сума грошей необхідна в середньому кожній людині на місяць, щоб не відчувати себе бідною (табл. 5).

Табличя 5

Розподіл домогосподарств за розміром середньодушового грошового доходу, достатнього, щоб не відчувати себе бідним

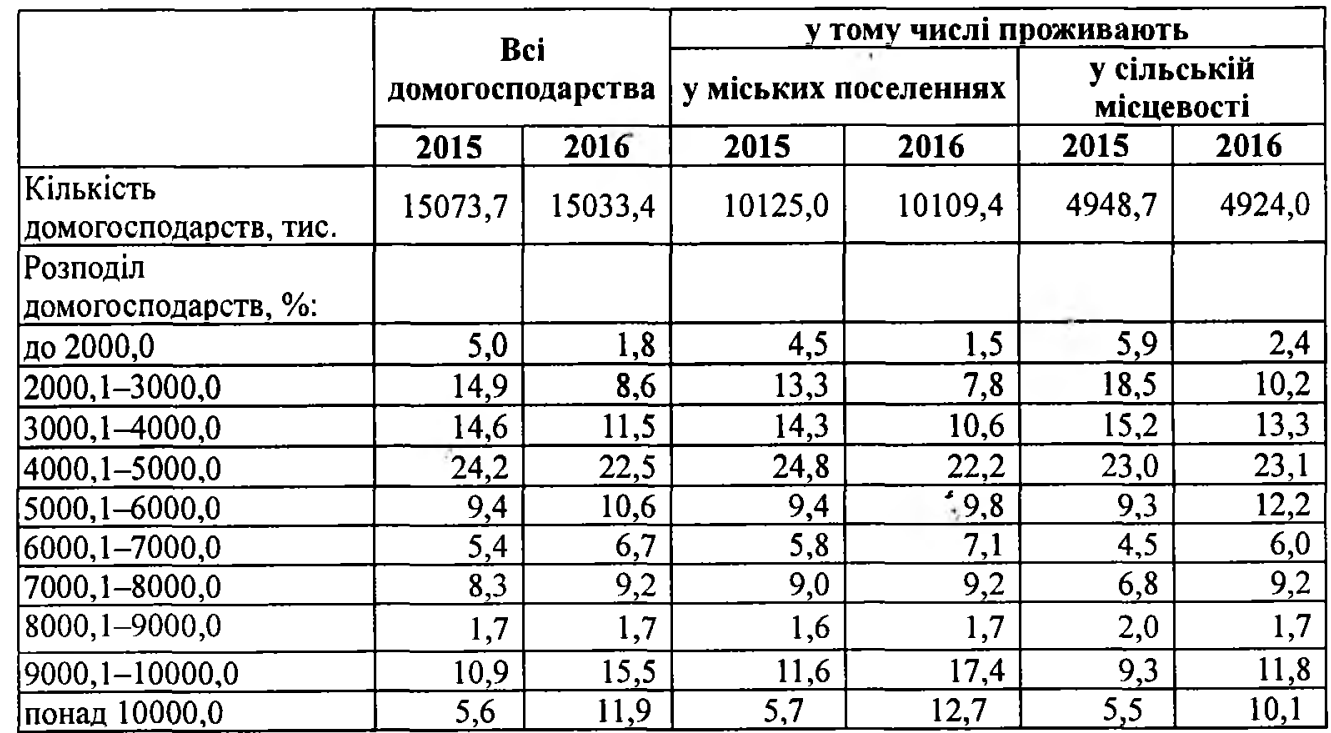

Джерело: побудовано за даними [12] 
Найбільша частка домогосподарств (22,2\% - міських; 23,1\% - сільських) у 2016 р. вказала доход у розмірі 4000,1-5000,0 грн. Наступним за ступенем поширення для міських домогосподарств був доход у розмірі 9000,1-10000,0 грн, про який повідомили $15,5 \%$ респондентів. Для сільських домогосподарств друге місце в цьому рейтингу посідає доход у розмірі 3000,1-4000,0 грн (13,3\%).

У вибірковому опитуванні членів домогосподарств щодо самооцінки рівня їхніх доходів для дослідження питань суб' ективної бідності та соціальної самоідентифікації домогосподарствам також пропонусться визначити, до якого класу за оцінкою матеріального добробуту вони себе відносять. За результатами опитування до бідних віднесли себе 72,4\% міських домогосподарств (у 2015 р. - 70,8\%) та 77,4\% сільських домогосподарств (у 2015 р. - 75,5\%) [12]. До представників середнього класу себе віднесли $0,7 \%$ міських та $0,3 \%$ сільських домогосподарств.

Висновки. Аналіз чинників та умов формування доходів населення свідчить про низький рівень життя в Україні, глибоку диференціацію доходів та загрозливі масштаби бідності. Головним джерелом доходів населення країни $є$ заробітна плата, незначну частку в структурі доходів мають доходи від власності. Номінальна заробітна плата щорічно зростає, проте ії розмір в доларовому еквіваленті протягом 2012-2016 рр. зменшився вдвічі. За результатами вибіркового опитування членів домогосподарств щодо самооцінки рівня їхніх доходів до представників середнього класу себе віднесли $0,7 \%$ міських та 0,3\% сільських домогосподарств. Незадовільними є механізми державного регулювання доходів та заробітної плати шляхом диференційованого оподаткування різних груп населення, потребує подальшої розбудови фондовий ринок країни з метою зростання доходів від власності, $\epsilon$ необхідність у більш досконалому обгрунтуванні розмірів мінімальної заробітної плати.

\section{Список використаних джерел}

1. Статистична інформація з офіційного веб-сайту Державної служби статистики [Електронний ресурс]. URL: http://www.ukrstat.gov.ua.

2. Слава С. С., Висіч О. В., Павлович В. І. Динаміка показників ефективності регулювання оплати праці в Україні // Науковий вісник Ужгородського університету. 2014. Вип. 3(44). С. 20-24.

3. Інформація з офіційного веб-сайту Міністерства фінансів України [Електронний pecypc]. URL: https://www.minfin.gov.ua.

4. Витрати і ресурси домогосподарств України у 2016 році (за даними вибіркового обстеження умов життя домогосподарств України): стат. зб. К.: Державна служба статистики України, 2017.380 с.

5. Поліщук О. Нерівність доходів по-українськи [Електронний ресурс]. URL: https:// www.ukrinform.ua.

6. Карпенко Н. В. Теоретико-методологічні аспекти державного регулювання доходів населення // Вісник соціально-економічних досліджень: зб. наук. пр. / Ред. М. І. Звєряков; Одеський держ. екон. ун-т., 2008. № 32. С. 164-169.

7. Мельниченко О. А., Гулій Р. М. Мінімальна заробітна плата як засіб державного регулювання трудових доходів населення [Електронний ресурc]. URL: www.irbisnbuv.gov.ua.

8. Середній клас в Україні: життєві цінності, готовність до асоціації і просування демократичних норм і стандартів (аналітична доповідь Центру Разумкова) // Національна безпека і оборона. 2014. № 1-2. С. 3-79.

9. Драган О.О. Заощадження домогосподарств як джерело інвестицій у національну економіку // Науковий вісник Херсонського державного університету. 2015. Вип. 10. Ч. 2. С. $132-135$.

10. Кочемировська О. О. Розвиток трудового потенціалу як чинник економічного зростання України: аналіт. доп. К.: НІСД, 2014. 108 с.

11. Титиш Г. Як це у них. Естонський досвід реформи середньої освіти [Електронний pecypc]. URL: http://life.pravda.com.ua/society/2016/06/13/213508.

12. Самооцінка домогосподарствами України рівня своїх доходів (за даними вибіркового опитування домогосподарств у січні 2017 року): стат. 3б. К.: Держстат України, 2017. 77 с. 
T. С. ИГНАТЕНКО,

aспирант,

ГВУЗ «Университет банковского дела» Начионального банка Украинын

\section{Факторы формирования и регулирования доходов населения Украины в контексте становления среднего класса}

Исследованы структура и динамика доходов населения Украины; проанализировано состояние государственного регулирования доходов и заработной платы; проведено оченивание уровня занятости как предпосылки увеличения доходов населения. Сделан вывод о необходимости совериенствования механизмов государственного регулирования доходов, дальнейиего развития фондового рынка и более совериенного обоснования размеров минимальной заработной платы.

Ключевые слова: средний класс, доходы населения, заработная плата, минимальная заработная плата, доходы от собственности, дифференцированное налогообложение.

T. S. IHNATENKO,

Poste-graduate Student,

"Banking University"

of National Bank of Ukraine

\section{Factors for Formation and Regulation of the Ukrainian Population's Incomes in the Context of the Middle Class Formation}

A key criterion for identification of the middle class is income level enabling for the households' consumption by the socialy acceptable standards. The share of middle class can grow only in parallel with the increasing polulation incomes. The article's objective is to study incomes of the Ukrainian population in the context of the middle class formation and analyze regulatory mechanisms pertaining to the populations' incomes and wages in Ukraine.

The study is based on the official statistical data for 2012-2016 (population's incomes and employment, nominal sages in hryvnya and dollar equivelant). The Kaitz index is calculated for Ukraine by data for 2015-2017. An extendive review of the data obtained from the sample survey of householdes on self-assessment of their incomes, conducted in January 2017, is given.

The analysis of factors behind the formation of population's incomes in Ukraine gives evidence of the low life standards in Ukraine, the wide income gap and the threatening scales of poverty. The main source of the population incomes in Ukraine is salary, with the insignificant share of income from property. While the nominal wage was growing year-to-year in 2012-2016, its dollar equivalent reduced twofold. According to the data of the abovemenationed sample survey, only $0.7 \%$ of city households and $0.3 \%$ of rural ones classified themselves in the middle class. Ukrainian still lacks appropriate mechanisms for regulation of incomes and wages through differentiated taxation of various population strata; the domestic stock market needs to be built in as way to ensure the increasing incomes from property; the rate of minimal wage should be better justified.

Keywords: middle class, population income, wage, minimum wage, income from property, differentiated taxation.

Посилання на статтю:

Ігнатенко Т. С. Чинники формування та регулювання доходів населення Украӥни в контексті становлення середнього класу // Науковий вісник Національної академії статистики, обліку та аудиту: 3б. наук. пр.. 2017. №4. С. 71-78.

SCIENTIFIC BULLETIN OF THE NATIONAL ACADEMY
OF STATISTICS, ACCOUNTING AND AUDIT, 2017, № 4

